\title{
Access to livelihood capitals and propensity for entrepreneurship amongst rice farmers in Ghana
}

Eliasu Mumuni* and Oladimeji Idowu Oladele

\begin{abstract}
Background: This paper examines rice farmers' access to livelihood capitals (natural, financial, physical, social and human) and the relationship and propensity for entrepreneurship capacities amongst rice farmers in the northern and Ashanti regions of Ghana. A simple random and purposive sampling method was used to select a sample size of 301 rice farmers in the two regions. A structured questionnaire was used in conducting the study. The data was analysed with IBM SPSS version 21 using frequencies, percentages, means and standard deviation. Wilcoxon sign rank test, paired $t$ test and Pearson correlation coefficient were also used for the analysis on the access to livelihoods, significance and relationship to entrepreneurial activities of the farmers.
\end{abstract}

Results: Farmers'access to natural capitals was stronger. Similarly, the Wilcoxon sign rank test and test statistics for the physical capital also revealed a significant difference in the farmers' physical capitals with all the measured variables including irrigation infrastructure $(z=-5.581 ; p=0.000)$, processing facilities $(z=-5.904 ; p=0.000)$, and market access $(z=-6.171 ; p=0.000)$, after been exposed to the technology interventions. The test statistics shows significant difference in all the measured variables with the $p$ value $(p>0.05)$ for the human capitals of the farmers. It also showed that farmers' credit from family and friends, access to bank loans and loans from farmer groups all increased from 47 to $52 \% ; 26$ to $37 \%$ and 28 to $78 \%$, respectively. Generally farmers' access to all the five livelihood capitals was significant and higher. On the access to livelihood capitals and its entrepreneurial abilities, natural capitals before ( $t=1.789, p=0.074)$, natural livelihood after $(t=1.664, p=0.096)$, social capital after $(t=1.838, p=0.066)$, and physical capital before $(t=2.87, p=0.004)$ showed a significantly positive relationship with their entrepreneurial capacities.

Conclusions: The study revealed that farmers' access to stronger livelihood capitals improves on their internal locus of control, improves their farming management abilities and ultimately boosts their agricultural entrepreneurial capabilities. The study recommends that farmers should leverage on their human capitals (farming skills taught them) to improving on all other livelihood capitals for better business sense and culture and entrepreneurial skills.

Keywords: Livelihood capitals, Farmers, Rice, Entrepreneurship, Agriculture, Ghana

\section{Background}

Agriculture is a greater contributor to poverty through jobs creation, food security and availability to world economies [1, 2]. Approximately 1.5 billion people are engaged in smallholder agriculture across the world.

\footnotetext{
*Correspondence: mumunieliasu@gmail.com; 24818062@nwu.ac.za Department of Agricultural Economics and Extension, North West University, Mafikeng Campus, Private Bag X2046, Mmabatho 2735, South Africa
}

They include $75 \%$ of the world's poorest people, whose food, income and livelihood prospects depend on agriculture [3]. It is undoubtedly seen as a bigger contributor to reducing poverty in a mass form than any other intervention according to [1]. By 2050, Africa's population will be 1.7 billion people [4] putting an overwhelming pressure on agriculture to feed the people and create jobs. These jobs will not only come from primary production of crop commodities and livestock, but through 
entrepreneurship as well. This is because of the shift in primary production to feed an agro-based processing paradigm and the wider expansion and involvement of other stakeholders in development. According to [5], the support to this shift from primary to processing, entrepreneurship and innovation stem from the support of agricultural extension support services and agricultural pro policies.

People's ability to escape poverty depends on access to assets or livelihood capitals [6]. This means that sustainable livelihoods are achieved through access to a range of livelihood resources (natural, economic, human, social and physical capital) which are combined in the pursuit of different livelihood strategies [7]. Rice is a critical, important and a major food security crop in Ghana where about 950,000-1,644,221 metric tons are consumed annually $[8,9]$, but can only produce $580,000-$ 600,000 metric tons leaving a huge deficit gap. The rice farmers who produce rice as a cash crop to supplement household's income see themselves as entrepreneurs. Combining all sources of available resources to produce, process, store, transport and sell to consumers or other actors along the rice value chain are what they do as small-scale farmer entrepreneurs. The rice production process is considered a major livelihood option that depends on the available livelihood capitals. These livelihood capitals (natural, physical, human, social and financial) are a major asset for every individual wellbeing which are in different proportions of access and availability $[7,10]$.

Based on the sustainable livelihood framework, [11] explains livelihood as 'the activities, the assets, and the access that jointly determine the living gained by an individual or a household'. He further defined 'rural livelihood diversification' as 'the process by which households construct a diverse portfolio of activities and social support capabilities for survival and in order to improve their standard of living. The diverse portfolio of activities requires some level of innovation and entrepreneurship to improve rural livelihoods and create enabling business opportunities and incomes. It helps to influence rural livelihoods through decisions they make about the management of their wealth or capital resources in their households.

Human capital describes the availability of farmers, rice processors, rice marketers, agro-inputs dealers, labour and agricultural technical officers who have the skills, knowledge, ability to utilise their capabilities to undertake rice production as their livelihood option. The type of knowledge and experience applied on the pre- and post-production scale of rice directly relates to the outcomes. The experience, skill and knowledge again help to minimise the adverse effects of vulnerabilities the production processes are exposed to. Farmers' ability to select good seeds, prepare and keep good records of their incomes and expenditures incurred, appropriate agronomic practices on the life cycle of the rice plant and the right technique to reduce post-harvest losses will inure to a good yield and income. Family labour is an important form of human capital according to [12]. The quality of the rice produced will also be good, making rice millers and marketers get return on their investment because customers will have value for their money. This process will result in a sustainable livelihood process for all the actors in the chain including labour that drives the activities of the production process with guaranteed wage.

The social capitals of farmers include family, friends, trust, norms, communality, gatherings, and networks of farmer associations and other actors like agro-inputs dealers, land owners and agricultural extension officers. All the networking within these knowledge communities does that with a common purpose and interest. Availability and accessibility to the rice production technologies, and rate of adoption by the farmers have stronger links to their social capital. Social networks may indirectly affect agricultural productivity by influencing farming practices and the household's propensity to adopt newer technologies via the supply of information through these networks $[13,14]$. The networking and membership allow them to learn from each other and depend on specific individual capabilities for their own benefits. Farmers' adoption levels also increase if they are influenced by their colleague's farmer other than outsiders. Memberships in more formalised groups (farmer-based organisations) often adhere to mutually agreed or commonly accepted rules, norms and sanctions. This improves their yields and livelihood outcomes with good strategies to manage the rice farming variabilities. More so, labour which is a bigger agricultural capital is largely from family and hired source for rice production activities [15]. Therefore, family plays an important role in the labour sources for rice production which helps them to reduce cost and cope with the intensification process and the vulnerabilities involved, but can have an adverse impact if the bond and belongings are not there. The solidarity component with trust helps them in times of disasters like droughts, poor yields, pest and disease outbreaks and flooding by supporting each other with inputs and even labour in the affected member's farms.

Natural capital which includes improved access to land, land area cultivated agricultural, fertile soils, water availability and accessibility, pollution elements, livestock and crops are the main drivers of agriculture. Availability and access to these elements of natural capital depend on the capability of the farmers to accessing and utilising the resources. Rice is produced well under fertile soils 
and available water relying with the farmer's best use of knowledge and agronomic practices. The knowledge to maintain and sustain the availability of the natural capitals relates to the efficiency of the human capital and the shared values of the social capital. Watershed management and maintenance, not polluting the streams and canals for irrigation, dredging of the water ways, protecting the vegetation and good soil management help the farmer's production process, improving their coping mechanisms to shocks and vulnerabilities. More so, the maintenance helps in sustaining the availability of the capitals for continues use. Livelihood diversification of the available natural resources by the rice farmers can also help them cope with the disasters and vulnerabilities. Vegetables can be grown during the off-peak season of the production to improve their household incomes and financial capitals as well.

Rice farming is one of the livelihood sources with higher return on investments in Ghana aside cocoa [9] that help farmers to acquire physical assets. This fact means that production (acreage and yield), rice milling machines, power tillers, land, tractors and many others may be accessible to these farmers who have good return on their investment or otherwise good incomes. Farmers turn to invest more in housing, health care and education of their children [16]. Access to irrigation facilities, roads, storage and markets facilitates the strength of farmer's physical capital and improves the livelihood outcomes. The incomes generated from the production process provide cash to cover the expenses for their clothing, housing, education and other social amenities of the majority of people in rural areas [17]. Whereas the non-availability of the capitals weakens the resilience and coping mechanisms of these farmers during disasters or any adverse event like bush fires and droughts. The inter-relationship with social capital to physical is the link and network to seed and other input suppliers, ice millers, etc., which tends to a good will for the farmer and the other actors' concern. The financial capital of the farmer will have to be better and strong if the physical capitals are to be sustainable [18]. The knowledge, innovation and training of the farmer, and the processors as elements of human capital greatly contribute to a better coping strategy and recovery during difficulties and challenges. Government support to them in boosting their resilience will provide good roads for easy access, access to processing and bigger ware houses for their produce and easy land acquisition for rice production.

Financial capital is seen within the sustainable livelihoods framework as the financial resources people use to achieve their livelihood objectives. This capital in agriculture is generated and converted from farmers' product into cash for household expenses and also to be used for savings towards challenging times and bad seasons. Farmers depending on their trainings and support from extension officers can utilise formal and non-formal financial resources and institutions. This type of livelihood strategies and activities can guarantee the level of financial capital they can access or it is available to them. Ministry of Food and Agriculture (MOFA) [9] in their reports argues that farmers who are in stronger famerbased organisations (FBOs) which are a social capital element, could access financial support easily from local banks and microfinance companies as well from their own contributions than those who are not. It is inferred that a higher level of social and financial capital occurs in FBOs with internally generated revenue sources and savings culture [19]. This particular view had been earlier upheld by the [20] declaration that most successful groups are those in which a larger proportion of lending capital is derived from group members' savings. This will automatically add up to improve their coping mechanisms during hard times and better their livelihood outcomes. Aside converting their product into cash and getting support from financial institutions, labour works by the farmer and other diverse livelihood activities within the available period can result into a strong financial capital for the famers [21]. Whilst accessing the strategies and coping mechanisms of these rice farmers and the likely outcome from agricultural interventions and its entrepreneurial leverage, it is necessary to examine the policy and institutional context within which these capitals exist as espoused by $[7,10]$. Whilst some capitals may be vulnerable to certain shocks, it may be that authorities are able to act and limit any damage which occurs or perhaps provide recompense [22]. In this sense, the response and support of the district assemblies and the government agencies to the external threats of farmer's livelihoods is critical.

In complex changing economies that are globally linked with niche developmental trends, farmers need to be more entrepreneurial with business sense and approach. There is pressure for farmers to change their production roles to all-round entrepreneurship paradigms, diversifying away from the production of crops and livestock as raw commodities to an agro-based transformation and further up on the agricultural value chain [23]. Dealing with all rice value chain actors including input dealers, suppliers, transporters, farm labour, agricultural extension officers, marketers and consumers' etcetera requires some level of skills and assets. Farmers ability to deal with challenges such as vulnerability to production and postproduction shocks, access to finance and credit, access to required information, low bargaining power for their produce, unskilled or low technical knowledge etcetera relates to the strength of their livelihood capitals and how 
they access it [24]. In all these interplay, the relationship and propensity for entrepreneurship depend largely on the access to livelihood capitals and its level of proportions available to the rice farmers. This paper therefore aims to examine rice farmers' access to livelihood capitals (natural, financial, physical, social and human) and the relationship and propensity for entrepreneurship build up amongst them in Ghana.

\section{Methodology of the study}

\section{Study area and population of the study}

The study area covers the Ashanti and the northern regions of Ghana. Ashanti falls within the semi-deciduous agro-ecological zone of Ghana and is located by latitude $6^{\circ} 52^{\prime} \mathrm{N}$ and longitude $1^{\circ} 51^{\prime} \mathrm{W}$. The area is on an altitude of approximately $280 \mathrm{~m}$ above sea level. The region experiences double maximum rainfall in a year, with peaks in May/June and October. Mean annual rainfall is between 1100 and $2900 \mathrm{~mm}$. The mean annual temperature ranges between $25.5{ }^{\circ} \mathrm{C}$ in the southern districts and $32{ }^{\circ} \mathrm{C}$ in the northern parts of the region. Humidity is high averaging about $85 \%$ in the southern districts and $65 \%$ in the northern part of the region, whilst the northern region on its part occupies an area of about $70,383 \mathrm{~km}^{2}$ and represents the largest region in Ghana in terms of land area. The vegetation consists predominantly of grassland, typically Savannah with clusters of drought-resistant trees such as baobabs or acacias, mangoes and neem. Between May and October is the wet season, with an average annual rainfall of 750-1200 mm (30-40 in.). The dry season is between about November and April. The two regions have a total of over 7000 rice farmers according to MOFA [9] (Fig. 1).

With the approval and support of the MOFA in the Ashanti and the northern regions of Ghana through their district agricultural offices, a total of 301 rice farmers were selected for the interviews. These selected farmers were beneficiaries of a rain-fed lowland rice production project where technical agricultural interventions, skills and technologies were extended to them to improve their production and incomes ultimately. The project was supported by both the Government of Ghana (GoG) through the MOFA and the Japanese Government through Japan International Cooperation Agency (JICA) from 2009 to 2014 . With a total farmer population of 2221 of the project and a confidence level of 95 and $5 \%$ precision level, a sampling formula of $n=N / 1+N(e)^{2}$ was used to arrive at the sample size (301) in selecting the farmers, where $n=$ the sample size, $N=$ total farmer population and $e=$ error tolerance. Sarantakos Sotirios argues that a bigger sample size gives better accuracy than smaller sample sizes and lower sampling error [25]. Simple random sampling was done to select the 301 respondents for equal chance of representation of being part of the study. This

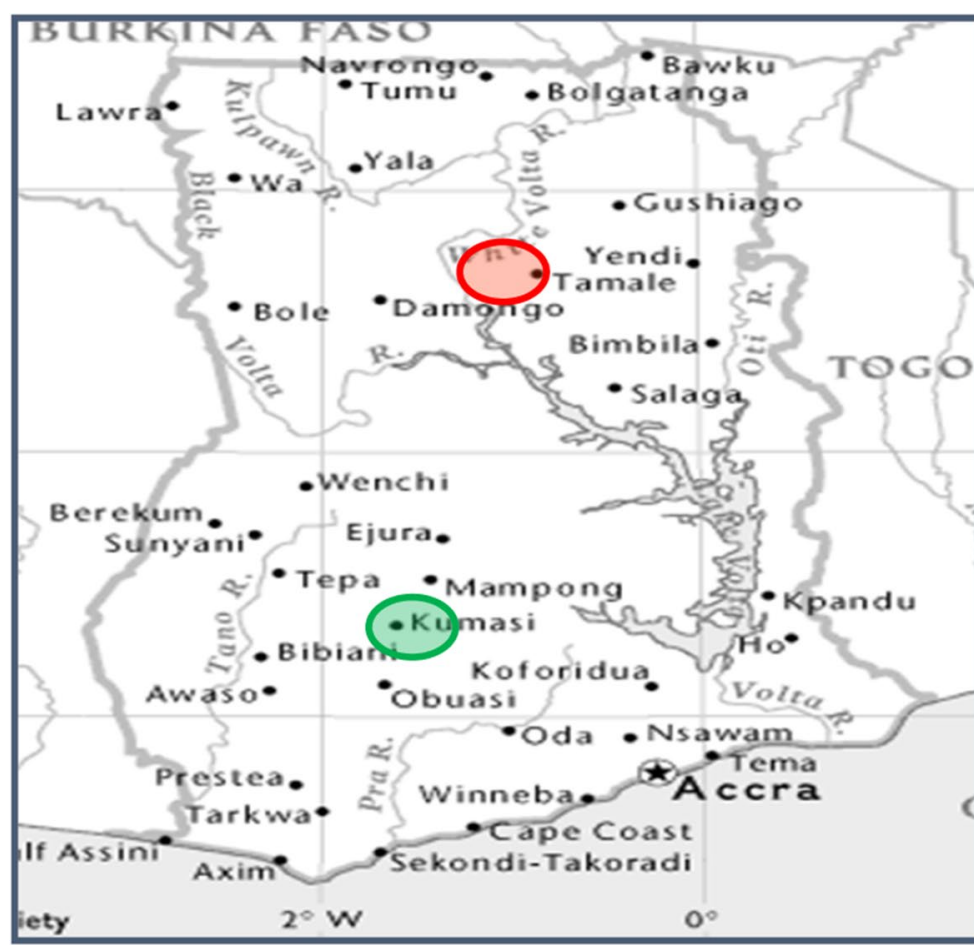

Northern Region

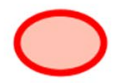

Ashanti Region

Fig. 1 Study area (source: GoG, 2011) 
method increases the probability of every respondent to be part of the study.

Open- and close-type questionnaires were used in conducting the study. The questionnaires were grouped based on the five livelihood assets classifications of the livelihood frameworks (Bio-data, rice farming, physical capital, social capital, human capital, financial capital, natural capital and entrepreneurship). A consent approval was sort from each rice farmer before the questionnaire administration began and the entire purpose of the study explained to them before the start of the study. The data collected were subjected to descriptive analysis with the use of frequency counts, percentages, and standard deviation. IBM-SPSS version 22 and Microsoft excel sheets were used to analyse the data.

\section{The Wilcoxon signed-rank sum test}

Wilcoxon theory of sign test compares two related samples like (before and after) with the same sample population for scoring and ranking [26]. The test applies to two-sample designs involving repeated measures and matched pairs, in this case for beneficiaries before and after the impact or differences on their livelihoods. The Wilcoxon signed-rank sum test as used in the study does not assume that the difference between the variables is interval or normally distributed but assumes that the differences are ordinal. The test is robust and highly efficient for moderate to heavy tailed underlying distributions. In particular, it is an improvement over the sign test and very efficient when the underlying distribution is normal [27]. Hettmansperger [27] further added that Wilcoxon signed-rank statistics can be computed as sign statistic of the pair-wise averages of data.

Mathematically, the explanation for the Wilcoxon signed-rank test for the study is as follows;

$$
W=\left|\sum_{i=1}^{N_{r}}\left[\operatorname{sgn}\left(x_{2, i}-x_{1, i}\right) \cdot R_{i}\right]\right|
$$

where $W=$ Wilcoxon signed-rank test, $N_{\mathrm{r}}=$ sample size, $X_{12}=$ measuring levels. For $I=1,2, \ldots, n, X_{1}\left(N_{1}, H_{1}, P_{1}\right.$, $\left.S_{1}\right)$ before the technology intervention; $X_{2}\left(N_{2}, H_{2}, P_{2}, S_{2}\right)$ after the technology intervention; $R_{i}$ rank; With $N$ natural capital, $H$ human capital, $P$ physical capital and $F$ social capital. Hence

$W=\left[\sum_{i=1}^{N_{r}} \operatorname{sign}\left(X_{2}\left(N_{2}, H_{2}, P_{2}, S_{2}\right)-X_{1}\left(N_{1}, H_{1}, P_{1}, S_{2}\right)\right) \cdot R_{i} \cdot\right]$

As $N_{r}$ increases, the sampling distribution of $W$ converges to a normal distribution.

The remaining $N_{r}$ pairs were ranked $\left(R_{i}\right)$ from the smallest absolute difference to the largest absolute difference of the capitals, thus $\left[X_{2}\left(N_{2}, H_{2}, P_{2}, S_{2}\right)-X_{1}\left(N_{1}, H_{1}, P_{1}, S_{2}\right)\right]$.

\section{The Probit model}

The Probit model is often used in situations where an individual makes choices between two alternatives. In this case, the decision is to either adopt or not adopt technologies or interventions in rice production to improve on their livelihoods and entrepreneurial activities. The Probit model was then used to determine farmer's entrepreneurial abilities as a result of access to the key livelihood capitals. Education, age, farming experience, income, market access, gender, extension services and the livelihood capitals were the expressed attributes hypothesised to determine the entrepreneurial propensity of the farmers. Farms and farmer-associated attributes are some of the factors influencing the adoption of new agricultural technologies to improve their livelihoods according to [28]. In the Probit model, the discrete dependent variable $Y$ is a rough categorisation of a continuous, but unobserved variable $Y^{\prime \prime}$.

If $Y^{*}$ could be directly observed, then standard regression methods would be used (such as assuming that $Y^{\prime \prime}$ is a linear function of some independent variables, for example,

$$
Y^{*}=\beta_{1} X_{1 i}+\cdots+\beta_{j} X_{j i}+\mu_{i} .
$$

In this study, $Y^{*}$ is entrepreneurial abilities which is used as a proxy for $Y^{\prime \prime}$. A Probit model is appropriate when the dependent variable to be evaluated is dichotomous [29].

Following from [30], the binary probit for the two choice models can be written as:

$$
\begin{aligned}
& Y_{i}^{*}=\left\{\begin{array}{cc}
1 & \text { if } Y_{i}^{*}>Y \\
0 & \text { if } Y_{i}^{*} \leq 0
\end{array}\right. \\
& P\left(Y=\frac{1}{X}\right)=F(X B)=\frac{1}{\sqrt{2 \pi}} \int_{-\infty}^{X B} \mathrm{e}^{\frac{-(X B)^{2}}{2}} \mathrm{~d} x \\
& X=\left(1, x_{1 i}, x_{2 i}, \ldots, x_{k i}\right) \\
& \beta^{\prime}=\left(\beta_{0}, \beta_{1}, \ldots, \beta_{k}\right)
\end{aligned}
$$

The actual model specification for farmer's entrepreneurial propensity as a result of access to the livelihood capitals is; $Y_{i}=\beta_{0}+\beta_{1}$ Age $+\beta_{2}$ Gender $+\beta_{3}$ Educational level $+\beta_{4}$ Age $+\beta_{5}$ Years of farming experiences $+\beta_{6}$ Income $+\beta_{7}$ Ready market $+\beta_{8}$ Extension contact $+\beta_{9}$ Human capital before $+\beta_{10}$ Human capital after + $\beta_{11}$ Natural capital before $+\beta_{12}$ Natural capital after + $\beta_{13}$ Social capital before $+\beta_{14}$ Social capital after $+\beta_{15}$ Financial capital before $+\beta_{16}$ Financial capital after + $\beta_{17}$ Physical capital before $+\beta_{18}$ Physical capital after + $\mu_{i}$ where $Y_{i}$ and $\mu_{i}$ represent farmers entrepreneurial propensity with access to livelihood capitals. 


\section{Results and discussion}

\section{Demographic characteristics of respondents}

Access to livelihoods and personal welfare improvement farmers depends on some qualities and characteristics. The demographic features of the respondents captured in Table 1 reveal that majority of the farmers were youthful with an average mean age of 36 years and years of farming experience averaging 11.13 years (Table 1 ). From Table 1, many of the youth are engaged in rice farming which is good for Ghana's present and future agriculture and also shows signs of progress which is contrary to [31] argument that majority of the youth in Africa do not have interest in agriculture.

The findings reveal that men dominates the rice production process with $86 \%$, and $14 \%$ female; however, the women have designated roles and responsibilities especially on transplanting, post-harvest, processing and marketing aspect of the rice value chain. This is consistent with Ghana's [32] policy framework for rice, which argues the issues of land tenure, access and ownership that prevented a lot of Ghanaian women from engaging in agriculture and rice farming, in particular when they are proved to be more credit worthy. Majority of the farmers had basic education level qualification and had access to market and extension services for their rice

Table 1 Demographic characteristics of respondents

\begin{tabular}{|c|c|c|c|}
\hline Variable & $N$ & Mean & Std. deviation \\
\hline Education & 301 & 1.17 & 1.63 \\
\hline Age (years) & 301 & 35.79 & 10.62 \\
\hline Farming experience (years) & 301 & 11.13 & 6.98 \\
\hline Income (amount) & 301 & 3496.53 & 3790.43 \\
\hline Ready market & 301 & 1.0432 & 0.36714 \\
\hline Extension contact & 301 & 1.8671 & 0.46434 \\
\hline Established market & 301 & 1.8704 & 0.37393 \\
\hline Gender & 301 & 61.6678 & 14.20361 \\
\hline Ready market & 301 & 608.0764 & 57.20773 \\
\hline Human capital before & 301 & 28.83 & 9.21 \\
\hline Human capital after & 301 & 55.82 & 6.51 \\
\hline Natural capital before & 301 & 8.59 & 3.48 \\
\hline Natural capital after & 301 & 22.24 & 3.48 \\
\hline Social capital before & 301 & 29.30 & 5.45 \\
\hline Social capital after & 301 & 29.39 & 5.60 \\
\hline Financial capital before & 301 & 11.36 & 1.58 \\
\hline Financial capital after & 301 & 8.90 & 3.48 \\
\hline Physical capital before & 301 & 16.79 & 2.94 \\
\hline Physical capital after & 301 & 11.98 & 3.30 \\
\hline Positive psychological capital before & 301 & 36.57 & 7.63 \\
\hline Positive psychological capital after & 301 & 20.81 & 5.60 \\
\hline Entrepreneurship ability before & 301 & 61.67 & 14.20 \\
\hline Entrepreneurship ability after & 301 & 608.08 & 57.21 \\
\hline
\end{tabular}

production with an average mean income of GHc 3496. The standard deviation for the livelihood capitals for before and after showed significant variance (Table 1) to the mean, an indication of improvements in their general livelihood abilities.

Non-farm income earnings for the farmers were very significant in supporting their household expenditures complimenting their agricultural incomes (Table 2). The varied sources of their incomes indicate how entrepreneurial the farmers are through generating many activities that create employment. The three sources of income-generating activities if combine for a season means that the rice farmers' financial capitals and household incomes are stronger. As farmer entrepreneurs, source of funding for their agricultural activities is critical to their farming business sustenance. Personal savings and rice buyers were their major source of funding in addition to their relative and cooperatives (Fig. 2).

\section{Access to livelihood capitals by respondents}

About 83 percent of the farmers responded that they had good and strong access to natural capitals including agricultural land, water and the vegetation (Table 2). The access margins include usage and access of water utilisation (82\%), land access and utilisation (73\%), tenancy arrangement (70 \%) and fertility management of the lands/soil (66\%). Their access margins to these resources drastically improved or increased from their early experience without the project. Similarly, all the variables showed very high levels of significance with the test statistics ( $t$ test) which include water utilisation $(z=-15.391 ; p=0.000)$, land access and utilisation $(z=-10.222 ; p>0.05)$, tenancy arrangement $(p=0.000)$ and fertility management of the lands/soil $(p>0.05)$. The higher response of access to natural capitals with a strong significant $p$ value score indicates the opportunity for them to expand their farming business to take advantage of the availability and access of the common pool natural resources. Generally, agriculture thrives on the availability and access to these resources for production [33].

Farmers' access to physical capitals also reveals some remarkable changes apart from farm roads with low response of $(24 \%)$ after the project (Table 2). Market access (from 31 to $71 \%$ ), processing facilities (mills) (from 57 to $78 \%$ ), housing facilities (from 43 to $63 \%$ ), for health (from 37 to $51 \%$ ), irrigation infrastructure (from 37 to $51 \%$ ), farm sheds (from 57 to $78 \%$ ) and net scare crows (from 43 to $63 \%$ ) all show an incremental level of change from before the project to after the project. The Wilcoxon sign rank test and test statistics for the physical capital also revealed significant differences in the farmers' physical capitals with all the measured variables (Table 2) including irrigation infrastructure $(z=-5.581$; 
Table 2 Access to livelihood capitals of respondents

\begin{tabular}{|c|c|c|c|c|c|c|c|c|}
\hline \multirow{2}{*}{$\begin{array}{l}\text { Livelihood capitals } \\
\text { Levels }\end{array}$} & \multicolumn{2}{|c|}{$\begin{array}{l}\text { Before the } \\
\text { technology } \\
\text { intervention }\end{array}$} & \multicolumn{2}{|c|}{$\begin{array}{l}\text { After the } \\
\text { technology } \\
\text { intervention }\end{array}$} & \multicolumn{4}{|c|}{ Wilcoxon signed ranks test } \\
\hline & High & Low & High & Low & $\begin{array}{l}\text { Negative } \\
\text { ranks }\end{array}$ & $\begin{array}{l}\text { Positive } \\
\text { ranks }\end{array}$ & $\begin{array}{l}Z \text { score } \\
\text { coefficient }\end{array}$ & $\begin{array}{l}\text { Asymp. sig. } \\
\text { (2-tailed) }\end{array}$ \\
\hline \multicolumn{9}{|l|}{ Natural capital } \\
\hline Land access and utilisation & $137(46)$ & $172(57)$ & $218(73)$ & $81(27)$ & 89 & 89 & -10.222 & 0.0000 \\
\hline Water utilisation & $98(33)$ & $186(62)$ & $245(82)$ & $55(18)$ & 246 & 121.5 & -14.829 & 0.0000 \\
\hline Land tenure arrangement & $90(30)$ & $208(69)$ & $211(70)$ & $87(29)$ & 218.73 & 132.5 & -15.065 & 0.0000 \\
\hline Payment for land if rented & $189(63)$ & $91(30)$ & $223(74)$ & $77(26)$ & 78.5 & 78.5 & -11.609 & 0.0000 \\
\hline Land quality and fertility of soil & $131(44)$ & $162(54)$ & $198(66)$ & $101(34)$ & 128.85 & 121.5 & -9.2 & 0.0000 \\
\hline Watershed development and conservation facilities & $79(26)$ & $162(54)$ & $157(52)$ & $142(47)$ & 120.91 & 75.8 & -4.311 & 0.0000 \\
\hline Water streams & $164(55)$ & $146(49)$ & $155(52)$ & $140(47)$ & 98 & 115.67 & -10.4 & 0.0000 \\
\hline \multicolumn{9}{|l|}{ Physical capital } \\
\hline Road and transport to the farms & $53(18)$ & $247(82)$ & $73(24)$ & $227(76)$ & 34.85 & 28.5 & -5.958 & 0.0000 \\
\hline Market access & $92(31)$ & $172(57)$ & $212(71)$ & $88(29)$ & 29.1 & 28 & -6.171 & 0.0000 \\
\hline Silos/storage facilities & $12(42)$ & $162(54)$ & $145(48)$ & $155(52)$ & 33.17 & 30.5 & -4.130 & 0.0000 \\
\hline Farm sheds & $171(57)$ & $128(43)$ & $235(78)$ & $65(22)$ & 32.74 & 39.23 & -4.376 & 0.0000 \\
\hline Agricultural machinery & $133(44)$ & $176(59)$ & $147(49)$ & $152(51)$ & 35.68 & 37.73 & -5.581 & 0.0000 \\
\hline Irrigation infrastructure & $112(37)$ & $184(63)$ & $153(51)$ & $143(47)$ & 38.34 & 35.5 & -6.524 & 0.0000 \\
\hline Netting scare crows & $128(43)$ & $172(57)$ & $189(63)$ & $99(33)$ & 37.01 & 47.32 & -5.328 & 0.0000 \\
\hline Processing facilities (mills) & $171(57)$ & $128(43)$ & $235(78)$ & $65(22)$ & 35.87 & 46.19 & -5.904 & 0.0000 \\
\hline Housing facilities & $128(43)$ & $172(57)$ & $189(63)$ & $99(33)$ & 34.14 & 57.33 & -5.045 & 0.0000 \\
\hline Health facilities & $112(37)$ & $182(61)$ & $153(51)$ & $144(48)$ & 25.38 & 32.54 & -3.072 & 0.0020 \\
\hline Telephone access & $129(43)$ & $172(57)$ & $190(63)$ & $99(33)$ & 24.25 & 29.5 & -2.354 & 0.0190 \\
\hline \multicolumn{9}{|l|}{ Human capital } \\
\hline Extension services & $137(46)$ & $161(54)$ & $198(66)$ & $97(32)$ & 118 & 128 & -12.655 & 0.0000 \\
\hline Rice skills training & $98(33)$ & $187(62)$ & $267(89)$ & $32(11)$ & 179.47 & 132 & -14.267 & 0.0000 \\
\hline Technical training & $99(33)$ & $189(63)$ & $269(90)$ & $33(11)$ & 141 & 141 & -15.391 & 0.0000 \\
\hline Land management training & $92(31)$ & $165(55)$ & $187(62)$ & $86(29)$ & 138.5 & 138.5 & -15.229 & 0.0000 \\
\hline Disease treatment & $134(45)$ & $162(54)$ & $254(85)$ & $46(15)$ & 138.5 & 138.5 & -15.229 & 0.0000 \\
\hline Water management & $121(40)$ & $173(58)$ & $215(72)$ & $78(26)$ & 141 & 161 & -15.391 & 0.0000 \\
\hline Soil management & $127(42)$ & $174(58)$ & $220(73)$ & $80(27)$ & 138 & 148 & -14.593 & 0.0000 \\
\hline Marketing skills & $93(31)$ & $197(66)$ & $187(62)$ & $92(31)$ & 138 & 138 & -14.111 & 0.0000 \\
\hline Level of education & $167(56)$ & $133(44)$ & $162(54)$ & $130(43)$ & 132 & 136.69 & -15.098 & 0.0000 \\
\hline Innovative and creative thinking & $88(29)$ & $181(60)$ & $121(40)$ & $173(58)$ & 124 & 125.59 & -13.977 & 0.0000 \\
\hline Knowledge of farm management & $87(29)$ & $178(59)$ & $137(46)$ & $165(55)$ & 114.5 & 116.14 & -12.501 & 0.0000 \\
\hline Record keeping & $96(32)$ & $194(65)$ & $262(87)$ & $38(13)$ & 154.09 & 192.64 & -11.458 & 0.0000 \\
\hline Health status & $125(42)$ & $175(58)$ & $180(60)$ & $120(40)$ & 120 & 121.53 & -14.978 & 0.0000 \\
\hline Trainings and other services & $130(43)$ & $162(54)$ & $200(67)$ & $96(32)$ & 131.5 & 135.72 & -14.667 & 0.0000 \\
\hline \multicolumn{9}{|l|}{ Social capital } \\
\hline Relationship with relatives/neighbours & $230(77)$ & $68(23)$ & $231(77)$ & $70(23)$ & 122.29 & 89.65 & -7.552 & 0.0000 \\
\hline Labour networking (for farm work) & $161(54)$ & $134(45)$ & $187(62)$ & $119(40)$ & 115.37 & 102.65 & -7.153 & 0.0000 \\
\hline Network with MOFA, AEAs and assemblies & $126(42)$ & $173(58)$ & $246(82)$ & $53(18)$ & 95 & 100.98 & -11.706 & 0.0000 \\
\hline Network with financial institutions & $54(18)$ & $165(55)$ & $143(48)$ & $160(53)$ & 77 & 83.96 & -10.927 & 0.0000 \\
\hline Network with transporters & $98(33)$ & $132(44)$ & $96(32)$ & $145(48)$ & 79.5 & 79.5 & -9.388 & 0.0000 \\
\hline Network with shop owners and input dealers & $97(32)$ & $168(56)$ & $154(51)$ & $143(48)$ & 106.32 & 98.6 & -10.205 & 0.0000 \\
\hline Network with processors & $125(42)$ & $175(58)$ & $197(66)$ & $102(34)$ & 96.5 & 98.16 & -8.395 & 0.0000 \\
\hline Network with millers & $134(45)$ & $165(55)$ & $243(81)$ & $52(52)$ & 88 & 91.46 & -11.201 & 0.0000 \\
\hline Network with farmers association (FBOs) & $156(52)$ & $140(47)$ & $251(84)$ & $49(49)$ & 74.5 & 92.71 & -9.849 & 0.0000 \\
\hline Network with other production group(NGOs and civic group & $118(39)$ & $182(61)$ & $132(44)$ & $165(55)$ & 69.5 & 74.58 & -10.628 & 0.0000 \\
\hline
\end{tabular}


Table 2 continued

\begin{tabular}{|c|c|c|c|c|c|c|c|c|}
\hline \multirow{2}{*}{$\begin{array}{l}\text { Livelihood capitals } \\
\text { Levels }\end{array}$} & \multicolumn{2}{|c|}{$\begin{array}{l}\text { Before the } \\
\text { technology } \\
\text { intervention }\end{array}$} & \multicolumn{2}{|c|}{$\begin{array}{l}\text { After the } \\
\text { technology } \\
\text { intervention }\end{array}$} & \multicolumn{4}{|c|}{ Wilcoxon signed ranks test } \\
\hline & High & Low & High & Low & $\begin{array}{l}\text { Negative } \\
\text { ranks }\end{array}$ & $\begin{array}{l}\text { Positive } \\
\text { ranks }\end{array}$ & $\begin{array}{l}Z \text { score } \\
\text { coefficient }\end{array}$ & $\begin{array}{l}\text { Asymp. sig. } \\
\text { (2-tailed) }\end{array}$ \\
\hline Network with Village committee & $132(44)$ & $165(55)$ & $195(65)$ & $106(35)$ & 57 & 71.81 & -7.053 & 0.0000 \\
\hline \multicolumn{9}{|l|}{ Financial capital } \\
\hline Farm incomes & $178(59)$ & $156(52)$ & $213(71)$ & $81(27)$ & 82 & 82 & -3.211 & 0.0010 \\
\hline Non-farm income/revenues & $67(22)$ & $98(33)$ & $164(55)$ & $100(33)$ & 50 & 55.38 & -3.475 & 0.0010 \\
\hline Savings & $133(44)$ & $167(56)$ & $189(63)$ & $117(39)$ & 81 & 89.02 & -5.250 & 0.0000 \\
\hline Self-help groups savings & $98(33)$ & $192(64)$ & $153(51)$ & $144(48)$ & 97.26 & 87.38 & -8.248 & 0.0000 \\
\hline Credits from relatives and friends & $142(47)$ & $109(36)$ & $156(52)$ & $131(44)$ & 71 & 78.12 & -8.493 & 0.0000 \\
\hline Access to bank credits & $49(16)$ & $250(83)$ & $111(37)$ & $184(61)$ & 80.5 & 82.47 & -6.710 & 0.0000 \\
\hline Self-help groups loan (FBOs) & $83(28)$ & $276(92)$ & $234(78)$ & $62(21)$ & 75.98 & 72 & -2.646 & 0.0080 \\
\hline
\end{tabular}

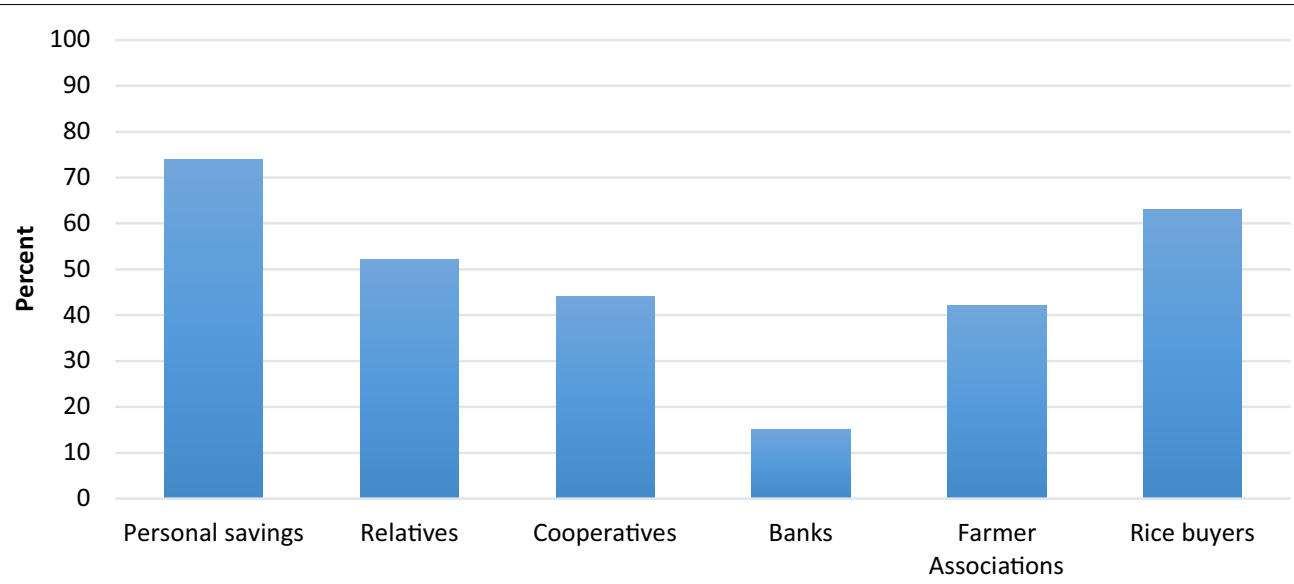

Fig. 2 Source of capital for farming

$p=0.000)$, processing facilities $(z=-5.904 ; p=0.000)$, housing facilities $(z=-5.045 ; p=0.000)$, market access $(z=-6.171 ; p=0.000)$, and telephone access $(z=-2.354 ; p=0.019)$, after been exposed to the technology interventions.

The level of farmers' human capital as observed from the study showed similar trend as the physical and natural capitals. Rice skill training for instance increased from 33 to $89 \%$, extension service from 46 to $66 \%$, and land management trainings of the farmers improved from 31 to $62 \%$. Also, the marketing skills increased from 32 to $66 \%$ before and after the project as well as from 9 to $46 \%$ for farmers' innovation and creativity from the study (Table 2). This affirms [34] findings that training of farmers by extension agricultural extension agents improves not only their production and skills but also their finances and household management. However, though many of the respondents experienced the change and improvements, a few others claim they did not experience any significant change in their human capital levels. The test statistics shows significant difference in all the measured variables with a $p$ value of $>0.05$.

The findings also show that farmers networking with the MOFA and the agricultural extension agents (AEAs) were very good. Their relationship with relatives and neighbours, labour networking (for farm work), network with financial institutions, network with farmers association (FBOs) as well as networking with input dealers had a strong $p$ value $(p>0.05)$ from the mean ranks which is an indication of strong access and improvements on their social capitals. Access to information and technology through networking with the relevant agencies improves farmers' performances and production abilities which lead to increase in entrepreneurial urge [35].

In addition, farmers' credit from family and friends , access to bank loans and loans from farmer groups all 
Table 3 Probit model analysis of livelihood capitals and entrepreneurial activity

\begin{tabular}{|c|c|c|c|c|}
\hline Parameters & Estimate & $\begin{array}{l}\text { Std. } \\
\text { error }\end{array}$ & $Z$ & Sig. \\
\hline Education & -0.029 & 0.006 & -4.818 & 0 \\
\hline Age & 0.003 & 0.001 & 2.83 & 0.005 \\
\hline Farming experience & 0.001 & 0.002 & 0.518 & 0.604 \\
\hline Income & 0 & 0 & -27.066 & 0 \\
\hline Gender & -0.049 & 0.02 & -2.522 & 0.012 \\
\hline Ready market & -0.065 & 0.03 & -2.194 & 0.028 \\
\hline Extension contact & 0.051 & 0.021 & 2.418 & 0.016 \\
\hline Established market & -0.143 & 0.028 & -5.157 & 0 \\
\hline Human capital before & 0.006 & 0.001 & 3.969 & 0 \\
\hline Human capital after & -0.001 & 0.002 & -0.741 & 0.459 \\
\hline Natural capital before & 0.007 & 0.004 & 1.789 & 0.074 \\
\hline Natural capital after & 0.005 & 0.003 & 1.664 & 0.096 \\
\hline Social capital before & 0 & 0.002 & -0.223 & 0.824 \\
\hline Social capital after & 0.005 & 0.003 & 1.838 & 0.066 \\
\hline Financial capital before & 0.002 & 0.007 & 0.225 & 0.822 \\
\hline Financial capital after & 0.006 & 0.005 & 1.278 & 0.201 \\
\hline Physical capital before & 0.013 & 0.005 & 2.87 & 0.004 \\
\hline Physical capital after & -0.02 & 0.003 & -6.158 & 0 \\
\hline $\begin{array}{l}\text { Positive psychological } \\
\text { capital before }\end{array}$ & 0.004 & 0.002 & 1.488 & 0.137 \\
\hline $\begin{array}{l}\text { Positive psychological } \\
\text { capital after }\end{array}$ & 0.002 & 0.003 & 0.533 & 0.594 \\
\hline Intercept & -1.133 & 0.192 & -5.895 & 0 \\
\hline Chi square & $13,319.44$ & & & \\
\hline$d f$ & 280 & & & \\
\hline$p$ & 0 & & & \\
\hline
\end{tabular}

Probit model: Probit $(p)=$ Intercept $+B X$

increased from 47 to $52 \%$; 26 to $37 \%$ and 28 to $78 \%$, respectively. The $z$ scores and the $p$ values (Table 2) showed significant changes and relationships; thus, farm incomes $(z=-3.211 ; p=0.001)$, non-farm income/revenues $(z=-3.475 ; p=0.000)$, savings $(z=-5.250 ; p=0.000)$, self-help groups' savings ( $z=-8.248 ; p=0.000)$, and selfhelp groups' loan (FBOs) $(z=-2.646 ; p=0.008)$. These results show a highly significant difference and change in their financial livelihood capitals on income, savings and credit affirming [36] position that agricultural credit and financing improve farmers' livelihoods and abilities.

\section{Relationship between access to livelihood capitals and entrepreneurship}

Undisputedly, farmers' main threat and challenge faced has always been strand or categorised into social barriers, economic barriers, physical barriers, regulations, access to finance and information dissemination and their managerial abilities to cope with and sustainably be in business as well as manage risk. Hence, threading from the stronger access of these livelihood capitals of the rice farmers from the above analysis, it is expected to either translate and contribute to better and stronger entrepreneurial farmers or not have a relationship whatsoever. The coefficients in the Probit model (Table 3) reveal a statistically significant relationship that shows that access to livelihood capitals can improve the entrepreneurial abilities of the respondents (Table 3). Age is significant $(t=2.83$ and $p=0.005)$, which means that young farmers with youthful strength are likely to develop more entrepreneurial abilities compared to the aged ones.

From Table 3, gender $(p=0.012)$, ready market $(p=0.028)$ for rice produce and contacts to extension officers $(p=0.016)$ were all significant. These revealed how the mutual distribution of roles in the farm is based on comparative advantage, available market to sell products and other value chain products that are linked to rice. Frequent contacts to extension officers on knowledge transfer also likely could increase the business and entrepreneurial propensities of the farmers. On the livelihood capitals, natural capitals before $(t=1.789$, $p=0.074)$, natural livelihood after $(t=1.664, p=0.096)$, social capital after $(t=1.838, p=0.066)$, and physical capital before ( $t=2.87, p=0.004)$ were all significant. Membership in multiple social networks and groups also enhances people's mental capability to perceive opportunity and additionally encourages their entrepreneurship abilities [37].

The probability of increased in entrepreneurial capacities of farmers increases with an increase in natural, social and physical capitals of farmers. The significant relationship of physical capital with entrepreneurship could be attributed to how transportation, farm machinery, market access, storage facilities and shelter can help propel entrepreneurial innovations. For social capital, the goodwill availability and the social relations and networks the farmers' access could improve their agricultural business sense and entrepreneur approach. Again, the results indicate that farmers had good access to natural capitals which is the foundation of rice farming. It could be attributed to how the access and use of land, available and access to agricultural water, however, could trigger entrepreneurial activities of farmers. These significant relationships established reveal the farmers abilities to take risk, improve on their internal locus of control and the need to achieve, and enhance their capabilities as farmers which are attributes of good entrepreneurs.

The scatter plot (Fig. 3) indicates a nonlinear relationship without layers between livelihood capitals and entrepreneurship abilities. 


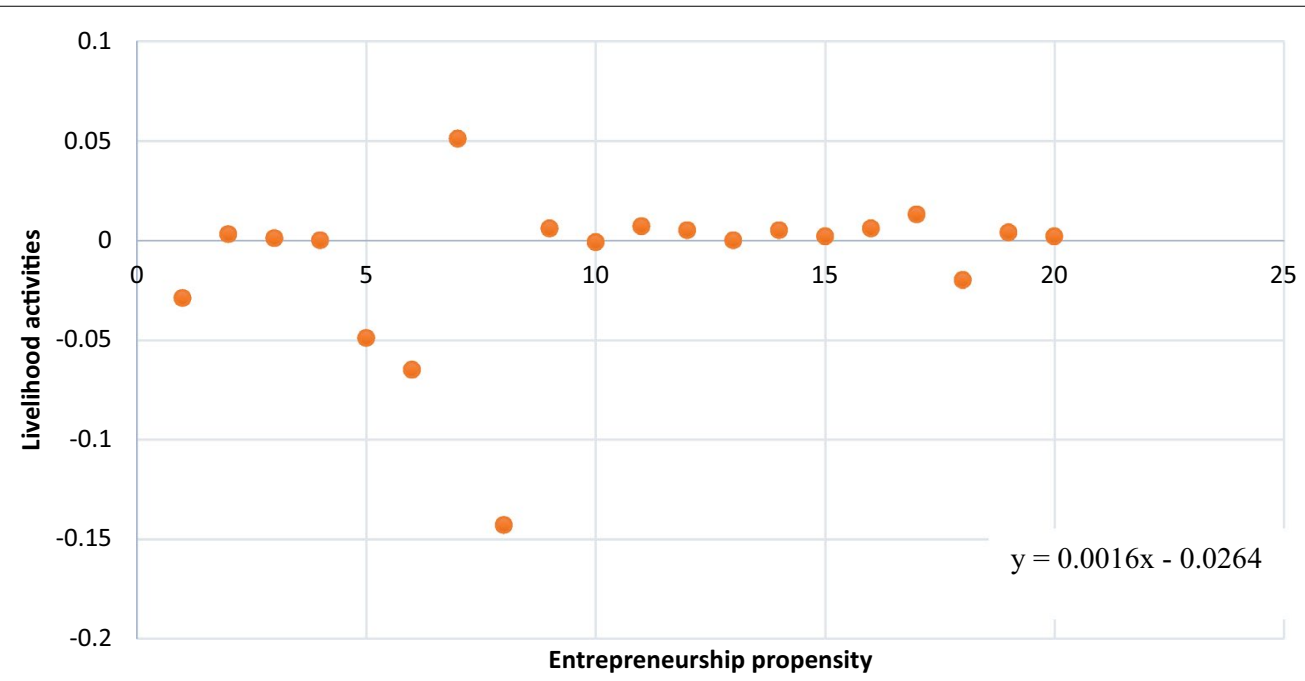

Fig. 3 Scatter plot of livelihood capitals and entrepreneurial activities

\section{Conclusion}

It can be concluded that labour is mutually shared for both males and females for the production (land preparation, weed control, fertiliser application and harvesting) and post-production (threshing, drying and cleaning) process of rice cultivation. Farmers' general access to all the key livelihood capitals strongly emerged from this research after the technology interventions. Since agriculture is the main livelihood source for the largely poor in developing and middle income countries like Ghana, a sustainable strategy of entrepreneurship propensity of farmers is the solution to many economic problems like urbanism, poverty, hunger, unemployment and economic under development. Access to stronger livelihood capitals like human skills development, knowledge of agriculture, knowledge of market, and management of the agricultural land, water resources, funding from banks and networking skills helps farmers develop strong and consolidated farming abilities. However, aside physical, natural and social livelihood capitals that showed a statistically significant relationship with entrepreneurial abilities, financial and human capitals were not significantly related though linearly correlated. The study recommends that farmers should leverage on their human capitals (farming skills taught them) to improving on all other livelihood capitals for better business sense and culture and entrepreneurial skills. Also, the business aspect of farming can be promoted by government to boost farmers' business skills and entrepreneurship capabilities too.

\section{Abbreviations}

MOFA: Ministry of Food and Agriculture; SRID: Statistics, Research and Information Department; JCA: Japan International Cooperation Agency; FBO: farmerbased organisations; GoG: Government of Ghana.

\section{Authors' contributions}

ME designed the data collection instruments and gathered the data, and helped in analysis and write up. OOI supervised the design, the entire data collection process and provided guide, corrections and supervision to the entire research. All authors read and approved the final manuscript.

\section{Acknowledgements}

The authors will like to thank the North West University (NWU) of the Mafikeng Campus, South Africa and Ministry of Food and Agriculture (MOFA), Ghana for their support.

\section{Competing interests}

The authors declare that they have are no competing interests.

Received: 24 October 2015 Accepted: 1 December 2015

Published online: 26 January 2016

\section{References}

1. OECD Economic Importance of agriculture for sustainable development and poverty reduction. Findings from a case study of Ghana. Econ Importance Agric Sustain Dev Poverty Reduct Find Case Study Ghana. 2010.

2. Dan Z, Wouter D, Chris DB, Tom C. Local bank financing for smallholder farmers: a $\$ 9$ billion drop in the Ocean. The Initiative For Smallholder Finance Briefing Paper 1; 2013. P. 1-6..

3. Ferris $\mathrm{S}$, et al. Linking smallholder farmers to markets and the implications for extension and advisory services. 2014.

4. FAO. How to feed the world in 2050. Forcast report; 2009. p. 1-35.

5. Lans T, Seuneke P, Klerkx L. Agricultural entrepreneurship. In: Carayannis EG, editor. Encyclopedia of creativity, invention, innovation, and entrepreneurship. Springer Reference. Berlin, Heidelberg: Springer; 2013. p. 1-6. doi:10.1007/SpringerReference_378865.

6. FAO. Socio-economic and livelihood analysis in investment planning $\odot$. 2008.

7. Scoones I. Sustainable Rural livelihoods: a framework for analysis. Ids Working Paper 72. 1998.

8. Millennium development authority. Investment opportunity in Ghana: maize, soya and rice production and processing. Accra; 2010.

9. MoFA. Agriculture in Ghana: facts and figures.Annual Report, Accra, Ghana; 2013. p. 1-64. 
10. GLOPP. DFID's sustainable livelihoods approach and its framework; 2008 p. 1-5. http://www.glopp.ch/website/en/technical_project.html.

11. Ellis F. Rural livelihood diversity in developing countries: evidence and policy implications. ODI Nat Resour Perspect. 1999:40:1-10.

12. Mahdi, Shivakoti GP, Schmidt-Vogt D. Livelihood change and livelihood sustainability in the uplands of Lembang subwatershed, West Sumatra, Indonesia, in a changing natural resource management context. Environ Manage. 2009;43:84-99.

13. Social capital and technology adoption on small farms. The case of banana production technology in Uganda. At http://repository.up.ac.za/ bitstream/handle/2263/24679/Complete.pdf?sequence $=14$.

14. Liverpool LSO, Winter-Nelson A. Poverty status and the impact of social networks on smallholder technology adoption in rural Ethiopia. IFPRI Discussion Paper 970; 2010.

15. Mumuni $E$, Yaa P, Oladele Ol. Household welfare among migrant rice farmers in Ashanti Region of Ghana. 2013;747-50.

16. MOFA. Status report on accessment of rainfed rice project outputs. 2013

17. Norman JC, Kebe B. African smallholder farmers: rice production. 2004;33-64.

18. District P, Province C, Pdr L. Impact assessment of livelihood interventions in BCl pilot site. In: Hasan Moinuddin, Jiao Xi, Sumit Pokhrel, Wang Wanying. 2009.

19. Akpabio IA. Significant predictors of social capital in farmers. J Int Soc Res. 2008;1/3 spring:1-11.

20. BankW. The world bank participation source book. 1996.

21. Food MA, Policies A, Fao M. Analysis of incentives and disincentives for rice in Ghana draft version. 2013.

22. Morse S, Mcnamara N, Acholo M. Sustainable livelihood approach: a critical analysis of theory and sustainable livelihood approach: a critical analysis of theory and practice. 2009.

23. Warren M. Farmers online: drivers and impediments in adoption of Internet in UK agricultural businesses. J Small Bus Enterp Dev. 2004;11:371-81.
24. Kahan D. The role of the farm management specialist by. 2013.

25. Sarantakos S. Social research. 1998

26. Wilcoxon F. Individual comparisons of grouped data by ranking methods. J Econ Entomol. 1946;39:269.

27. Hettmansperger TP, Oja H. Affine invariant multivariate rank tests for several samples. Stat Sin. 1998;8:785-800.

28. Mwanga J, Mussei A, Mwangi W, Verkuij H. Adoption of improved wheat technologies by small scale farmers in Mbeya district of southern highlands, Tanzania. Proc Tenth Reg Wheat Work East Cent South Africa Univ Stellenbosch South Africa 1418 Sept 1998. 2001;39-45. At http://repository.cimmyt.org/xmlui/bitstream/handle/10883/1021/74246.pdf.

29. Maddala GS. Limited-dependent and qualitative variables in economics. New York: Cambridge University Press; 1983. p. 257-91.

30. Greene WH. Econometric analysis. 2011.

31. Anyanwu C. Community development, the Nigerian perspectives. Gabesther Educational Publishers; 1992.

32. Republic THE. Ministry of food and agriculture the republic of Ghana national rice development strategy (NRDS) (DRAFT). 2009

33. FAO. Global agriculture towards 2050. High lev. expert forum-how to feed world 2050. 2009;1-4. At http://www.fao.org/fileadmin/templates/wsfs/ docs/Issues_papers/HLEF2050_Global_Agriculture.pdf.

34. Wellard K. Knowledge transfer: the role of community extension in increasing food security. 2011.

35. Ehmann M. Katalyst case study-7.pdf. 2014.

36. Minten B, Fafchamps M. Social capital and the firm: evidence from agricultural trade. Am J Agric Econ. 2001;83:65-98.

37. Dana L-P. Zotero groups IISES library toward a theory of social capital in entrepreneurship. Int J Soc Sci. 2012;35-54. At https://www.zotero.org/ groups/iises/items/G2V5X3PZ?fullsite $=0$.

\section{Submit your next manuscript to BioMed Central and we will help you at every step:}

- We accept pre-submission inquiries

- Our selector tool helps you to find the most relevant journal

- We provide round the clock customer support

- Convenient online submission

- Thorough peer review

- Inclusion in PubMed and all major indexing services

- Maximum visibility for your research

Submit your manuscript at www.biomedcentral.com/submit

() Biomed Central 